\title{
Impact of Motivations to Buy and Offer Gifts in Consumerism at Christmas
}

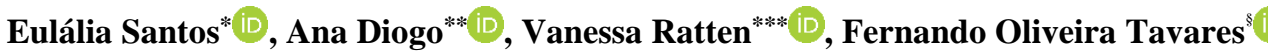

\begin{abstract}
This article aims to analyze a conceptual model composed of the variables motivation to buy, motivation to offer gifts and compulsive consumerism at Christmas time. In order to achieve the proposed objective, a quantitative methodology based on a questionnaire survey was used. The sample consists of 1086 Portuguese individuals, over 18 years old. To evaluate the model, structural equation modeling with partial least squares was used. The results show that the motivations to buy and to offer gifts positively influence compulsive consumerism at Christmas time, and that the motivation to buy positively influences the motivation to offer gifts at Christmas time. The model also demonstrates that the motivation to offer gifts plays a mediating role in the relationship between the motivation to buy and compulsive consumerism. In Portugal there are no known studies on the motivations for offering gifts at Christmas. The present study can help academics, researchers and professionals (managers of consumer goods companies, commercial managers and advertising campaign managers) to better understand the motivations for buying and offering gifts, and the compulsive consumerism of the Portuguese population at Christmas time.
\end{abstract}

Keywords: Christmas; Christmas gifts; consumerism; family; Santa Claus.

JEL classification: M20; M21; M31.

\section{INTRODUCTION}

Giving Christmas gifts is an important feature of Portuguese culture that involves a large part of the population and is responsible for important consumer spending, which leads to a great effort by families. According to Mesquita (1982) the importance that the Portuguese people give to the ritual of Christmas gifts it is impressive. Christmas consumerism is a reality of the present season, which encourages impulse buying. This annual festival is considered a

\footnotetext{
* Escola Superior de Tecnologia e Gestão do Instituto Politécnico de Leiria, Portugal; e-mail: eulalia.santos@ipleiria.pt (corresponding author).

** Instituto Superior de Gestão e Administração de Leiria, Portugal; e-mail: anabsousa@gmail.com.

**** Department of Management, La Trobe Business School at La Trobe University, Melbourne, Australia; e-mail: v.ratten@latrobe.edu.au.

${ }^{\S}$ ISCET - Higher Institute of Business and Tourism, Portugal; e-mail: ftavares@iscet.pt.
} 
magical time, as the best time of the year for sharing affections and love, when people live life more positively.

Santa Claus has reinforced a greater link between brands and the Christmas market (Gonçalves, 2020). In Portugal the image of Santa Claus is associated with the tradition of offering gifts. According to Levi-Strauss (2003) the figure of Santa Claus is the result of the secrecy between the Boy Bishop, elected under the invocation of Saint Nicholas, whose party goes back to the beliefs about socks and shoes in the fireplaces. Santa Claus is a figure based on initiation rites and myths with a practical function in human societies.

Gonçalves (2020) believes that Christmas elicits positive emotions, as the vast majority of respondents in his study reveal positive feelings about Christmas. However, people who participate less in Christmas rituals with the family and who do not have a good relationship with the family, do not have such an optimistic perception of Christmas.

To Gonçalves (2020) family, affection, love and caring are the most important aspects for happiness during Christmas. Materialism appears related to gifts and the tendency to buy on impulse. At Christmas time, shopping malls fill up with people, and there is a great diversity of advertising campaigns, so there is a reason to purchase goods, which is the tradition of offering gifts, which reassures and legitimizes the individual to acquire new material goods. Most people start shopping for Christmas a month before and until the days before the festivities; the week before Christmas Day it is the privileged time to accomplish this task (Gonçalves, 2020). E. Santos and Tavares (2020) conclude that the Portuguese estimate to spend less on consumer goods than on gifts. When the estimated money to be spent on gifts is higher, the estimated amount to be spent on consumer goods is also greater.

This article is relevant, because for Portugal, in the researches that we conducted we did not find studies on the motivation for purchases and gift giving, and it is essential to understand if these motivations lead to an increase in consumerism at Christmas. This article is relevant, because in the researches that we conducted we did not find studies in Portugal on the motivation for purchases and gift giving, and it is essential to understand if these motivations lead to an increase in consumerism at Christmas. In order to achieve this goal, in addition to this introduction, the article presents a literature review, which analyzes the motivation for offering gifts, consumption and the motivation to buy at Christmas time. The methodology section presents the population and the sample, the data collection instruments and the procedures taken into account when carrying out the research work. Then, the results are presented with a brief discussion. At the end of the article, conclusions, limitations, implications and proposals for future work are presented.

\section{LITERATURE REVIEW}

Christmas is celebrated on December $25^{\text {th }}$, more precisely in the winter season, but at the autumn already starts to smell like Christmas (Canhoto, 2018). A. C. Santos and Musse (2016) are also of the opinion that Christmas begins weeks before they are also of the opinion that Christmas starts weeks before. Christmas Day itself is a ceremony that results from several weeks of preparation. During these weeks, children write letters to Santa Claus telling Him the gifts they would like to receive, adults write cards for distant family and friends, the Christmas tree is chosen and decorated, the garland is placed on the front door, wrapping paper and colorful packaging are bought, the stockings are put up on the fireplace, gifts to offer and food for Christmas dinner are bought. During the $24^{\text {th }}$ there is a lot of activity in the kitchen, when the 
children go to sleep, the gifts are taken under the Christmas tree. Finally, on the 25th, there are trees with lights of various colors turning on and off, gifts, families gathered and children opening gifts and playing with them. In short, in the West, the celebration of Christmas involves the family, the exchange of gifts, the sending of messages, special decorations in shops, public places and homes, among other traditions (Pinto and Cruz, 2014).

For Lopes (2012) Christmas is the party that is most associated with commensality and where the foods to consume are more rigidly established. According to Mesquita (1982) the big supper, or consonant, also known as the family party, gathers most family members at the table. In the past, it was customary to hold the consonant dinner after the cock mass, however this tradition has been lost over the years, falling into disuse. In the elaboration of the menus, there are some heterogeneities of an anthropological character, resulting from the sociogeographic asymmetries. Thus, Christmas is the party that brings the family together, and it is also a period where there is a greater sensitivity alluding to the solidarity practice towards the most disadvantaged (Ferreira, 2019).

According to A. C. Santos and Musse (2016), Christmas can have different representations for each family member: for small children, it represents a fairyland with a bright tree, wonderful gifts, foods and sweets full of flavors. For older children, it is the time to reunite the family. For parents, it is the period that makes worthwhile all the effort weeks and even months of planning.

At Christmas, there is an appeal to consumption and the preservation of family memories and traditions (A. C. Santos and Musse, 2016), being considered the biggest consumption event of the year (Pinto and Cruz, 2014). Thus, Christmas, in addition to being relevant to consumption, represents a time when people seem to spend more freely on their preparation and appreciation (Clarke, 2007).

Christmas is one of the most important moments in the life of a Christian, it is the religious event in history that changed the world, being the most celebrated by believers and non-believers (Ferreira, 2019). Another tradition experienced at Christmas is the crib, which revives, through popular art, the biblical scenes related to the birth of Christ. Nativity scenes are a living lesson of brotherhood, love and humility (Mesquita, 1982).

\subsection{Motivation for gift giving}

In the study by Gonçalves (2020), the words most mentioned at Christmas time are, in this order: "family", "gift" and "light". The word "family" proves that this is an affective time, where the type of involvement and relationship with the family gains an important role in the perception of the quality of Christmas. The word "gift" refers to the fact that the exchange of gifts is a customary and traditional custom in this festive season and the word "light" refers to the most decorative aspect of the season and the magic that Christmas evokes.

Christmas and New Year holidays are global, but traditions vary by region. In some places, gifts are distributed on the night of December $24^{\text {th }}$, and in other places it is in the morning of the $25^{\text {th }}$, and there are still those who distribute the gifts on January $6^{\text {th }}$, Kings Day (Goidanich, 2008).

Corzo (2018) understands gifts as full of meaning, having, in Latin countries, the enjoyment of the exchange of gifts. The essence of the gift is the act of giving to another person. In the most collectivist countries, giving is important to consolidate friendly relationships. 
Therefore, there is an obligation and gifts are usually offered for no apparent reason. In the most individualistic countries, gifts are usually distributed only at important events.

Christmas is a party of a social nature, where gifts are valued (Silva, 2017). Celebrations of the birth of Christ have become the biggest gift distribution event (Storni and Estima, 2010), because for Christians the gifts express their joy at the birth of Jesus (Ferreira, 2019). The tradition of Christmas gifts is also mentioned in Bueno (2014), because according to the biblical account of the Gospel of Matthew, the Magi are those who come to worship the Messiah born King of the Jews. They come from the East, guided by a star, and they are magicians with offerings who come to worship the Christ. They offer the Child Jesus gold, incense and myrrh, worshiped the child, and paid homage to him with his gifts.

The gift is not just a meaningless thing or gift, it usually has social and cultural significance (Lemmergaard and Muhr, 2011). A gift reveals sympathy, appreciation, and is donated free of charge without expecting anything in return (Ferreira, 2019). According to Batinga et al. (2017), the act of giving can be defined as a symbolic exchange in social relations, and the gifts are imbued with cultural meanings and symbolic properties. Gifts extrapolate their commercial and utilitarian values, and are in constant motion, moving from a culturally constituted world, moving to their own good, for only then distance themselves from this and moving to the consumer, fitting to that assign its final meaning. Corzo (2018) also refers that culture is one of the factors that most influence the exchange of gifts between individuals, although other variables such as kinship, or proximity to the recipient, and the personality of each individual also have an influence.

According to Batinga et al. (2017) the so-called "Christmas spirit" would be responsible for causing a change capable of causing impersonal goods to be transformed into gifts exchanged within families, having as fundamental motivation the affection, for the consolidation of social ties, allowing the distancing from commodification and impersonality that characterize the modern world.

According to Lemmergaard and Muhr (2011), a gift has a considerable effect on a relationship, because of its emotional character. It can, however, strengthen and affirm a relationship, as well as cause negative emotions and thus weaken the relationship. Sometimes gifts can hurt and can easily become an act of subjection, as it puts the recipient in a position of reciprocity (Lemmergaard and Muhr, 2011).

Caplow (1984) says that at Christmas (individually or together) a gift is expected from each member of the family. Because of this rule, participants expect to receive at least one gift from each family member, except from the children. Gifts for grandparents and grandchildren are also mandatory, especially if they live in the same community or nearby. In a more distant family (uncles, cousins), gifts depend on reciprocity.

Lemmergaard and Muhr (2011) understand that the exchange of gifts between business partners at Christmas time is an attempt to cross over to the family's private market, trying to simulate a personal relationship by giving gifts. In the opinion of these authors, gifts are given to create personal connections and links between business relationships. When exchanging gifts between companies, giving is showing superiority and accepting without giving in return, or without giving more in return is to become a customer.

The study by Caplow (1982) indicates that in the United States people offered the essentials and in that order: clothes, toys, money, food / drinks, decorations / ornaments, hygiene items, household equipment, jewelry, appliances, sports equipment and plants. 
According to this author, money can be an appropriate gift from senior relatives to younger people.

Nicolás Ojeda et al. (2019) refer that, in Spain, Christmas is a period of the year with the highest sales rates of games for children, being considered the children's party to show positive emotions.

In the study by Deloitte (2018) the gifts that the Portuguese consider most likely to receive are in this order: chocolates $(54 \%)$, books $(53 \%)$, cosmetics $(47 \%)$, clothes $(47 \%)$, money $(36 \%)$, beauty care $(25 \%)$, accessories $(19 \%)$, CDs $(16 \%)$, sportswear $(16 \%)$.

Caplow (1982) noted that women are more active in giving gifts at Christmas, having found that they offer $84 \%$ of gifts. He also noted that gifts from men to men were rare. Men who work in social organizations give more gifts at Christmas, while women not connected to social organizations are less generous in the value of gifts and give fewer people (Fischer and Arnold, 1990).

Passos et al. (2020) observed in their quantitative study that, in addition to gender as a moderating variable, the study also considered the relationship between attitudes and behavior in the act of donating gifts. They note that, on Christmas gifts, there was a positive connection between attitudes and behaviors, because, in their opinion, obligation and pleasure had a positive effect. So, who gives with pleasure and makes a greater effort and gives more often. Passos et al. (2020) conclude that there are five values that have a direct relationship with the act of giving gifts: tradition, achievement, power, self-determination, and hedonism. According to these authors, self-determination and hedonism are the values that most influence behavior because they are the only ones to have positive effects on pleasure.

\subsection{Consumption and motivation to buy}

According to Gonçalves (2020), the word gift can be related to consumerism and materialism inherent to the time, and it can come with associated costs, pressure and stress. When the Christmas season approaches, the most common thoughts are reflected in what to buy, who to buy, and when to buy in order to give people a gift at Christmas. For Batinga et al. (2017), the act of buying as a gift - especially in family affective relationships as the main recipient of gifts - would be a way of making the transition from the universe of goods to the gifts world.

At the economic level, the gifts fit aspects valued by society, such as television advertising, and attractive storefronts, essentially with toys and motifs alluding to the time appealing to consumption (Silva, 2017). For Goidanich (2008), Christmas is a party that in the Christian tradition exists to celebrate life and family unity and has become over the years, also a celebration of consumption.

Consumption can be seen, according to Storni and Estima (2010), as an active mode of relationship with the community and the world, and a mode of systematic activity and response to capitalist production, on which the system is based on Western culture. Batinga et al. (2017) understand that consumption is cultural and all forms of consumption are culturally specific, since they are continuously articulated in relation to significant and specific ways of life.

Belk and Bryce (1993) evaluated two films produced at different times (one in 1947 and the other in the early 1990s) on the role of Christmas shopping. The results showed that Christmas has become a postmodern spectacle that reflects the disintegration of the individual 
in society. Gonçalves (2020) believes that the vast majority of respondents in his study reveal a positive position with regard to Christmas shopping.

In the opinion of Storni and Estima (2010), dates were created to stimulate purchases and have parties, such as birthdays, or other dates marked by religiosity, such as Christmas and Easter. On these dates, people participate through celebrations and increased consumption of food, gifts, clothes and props to decorate homes, among other objects sold. Storni and Estima (2010) also refer that the discourses and practices of consumption are generated by churches, sects and other forms of religiosity in general, with consumer items offered to individuals in the market, similarly to other symbolic goods, such as fashion, entertainment, lifestyle and identity.

Tavares et al. (2014) understand that trade assumes an important role in society, not only the economic, but also the social. Modern Western society created its symbols, based on commerce and it is this that gives life and animation to cities. Today, the concept of commerce tends to dematerialize and the association with leisure and the pleasure of family outings is increasingly an important point in choosing a shopping center to attend. It is therefore easy to understand, because the Portuguese prefer to shop at the mall. The shopping mall environment is designed to encourage impulsiveness and is also identified as a determining factor for the occurrence of impulsive purchases (Araújo and Ramos, 2010).

Consultant Deloitte (2018) noted that Portugal is in line with Europe with regard to the division of consumption by categories, presenting values similar to the European average. For the Portuguese, the reasons that lead them to spend more during the Christmas and New Year holidays are promotions, wanting to have fun and avoid thinking too much about the economic situation, the feeling of economic improvement, the newer things that encourage spend money, as well as retailers' services and recommendations to convince people to spend more money. Deloitte (2018) also noted that Portugal is in line with the European average in terms of money spent at this time of year, with a tendency to spend more on dates like Black Friday than in countries like Germany or the Netherlands, in which almost $50 \%$ of the population claims to spend nothing on these types of events. The Portuguese prefer to do their Christmas shopping at shopping centers (67\% of the answers), with the preferred payment method being the debit card, followed by payment in cash (Deloitte, 2019).

O'Cass and Clarke (2001) in an investigation into the preference of Australian children's Christmas product brands, through letters sent to Santa Claus, found that children are brandoriented in their Christmas shopping behaviors. But parents, while some toys stand out among store catalogs and brands do their promotions, are not familiar with the most popular brands when buying Christmas gifts for their children (Clarke and McAuley, 2010). Thus, the most popular source of information is to ask children what they want. According to Gonçalves (2020), Santa Claus has reinforced the greater link between brands and the Christmas trade, as the press articles report the great demand for specific toys and games during Christmas (Clarke and McAuley, 2010).

Fischer and Arnold (1990) understand that American Christmas celebrations seem to have multiple meanings that affect consumer performance. Men and women more connected to the community start shopping earlier, but women are more involved in Christmas shopping than men, and spend more time on each purchase. Men can take Christmas shopping a little lightly, considering it a joke, while women take Christmas shopping very seriously and see shopping as an important job (Fischer and Arnold, 1990). Mothers are also the ones who usually make the decision to buy gifts for their children (Clarke and McAuley, 2010). 
Araújo and Ramos (2010) they understand that the need to project social status through consumption, an attitude that in their study is related to shopping at the mall, gives a sense of power. They also identified close relationships between the feeling of being able to buy at the mall, impulsiveness and shopping, even if the person is not sure that he will be able to pay, thus identifying the occurrence of consumption aimed at ostentation. Fernandes (2020) also agrees that consumers seeking status seem to buy more on impulse because they understand that it gives them social status.

Penaloza et al. (2018) consider three main aspects of the social representation of impulsive consumption:

- The lack of control/exaggeration, which means crossing limits, imbalance, excess addiction, and which highlights the negative importance of the concept and the importance of the consumer's characteristics;

- Purchasing without thinking or unplanned that only expresses the technical meaning of the term impulsive consumption;

- Debts, where it is observed that, in a certain way, there is an indication of the compensation of the possible consequences of impulsivity, on the part of consumers, leading them to indebtedness.

Penaloza et al. (2018) note that there is a multifaceted interaction between emotional and cognitive principles related to compulsive consumption. In other words, the impulse caused by the strong desire to consume induces an irresistible desire to act, often in an unbridled way. The fact that friends approve of buying behavior can provoke positive emotions that lead to a greater trend of impulse buying (Fernandes, 2020).

Demographic characteristics, such as income, education level, and age, influence impulse buying behavior in the shopping center environment, with younger and lower income consumers being the most influential (Araújo and Ramos, 2010).

Taking into account the objectives and the literature review carried out, the following hypotheses were formulated:

Hypothesis 1: The motivation to buy positively influences compulsive consumerism at Christmas time.

Hypothesis 2: The motivation to buy positively influences the motivation to offer gifts at Christmas time.

Hypothesis 3: The motivation to offer gifts positively influences compulsive consumerism at Christmas time.

In the conceptual model presented in Figure no. 1, the hypotheses under study are represented, being possible to observe that, according to Kisbu-Sakarya et al. (2020), it is a mediation model, where the independent variable (motivation to buy) causes the mediating variable (motivation to offer gifts), and the mediating variable conveys the effect of an independent variable on the dependent (compulsive consumerism). 


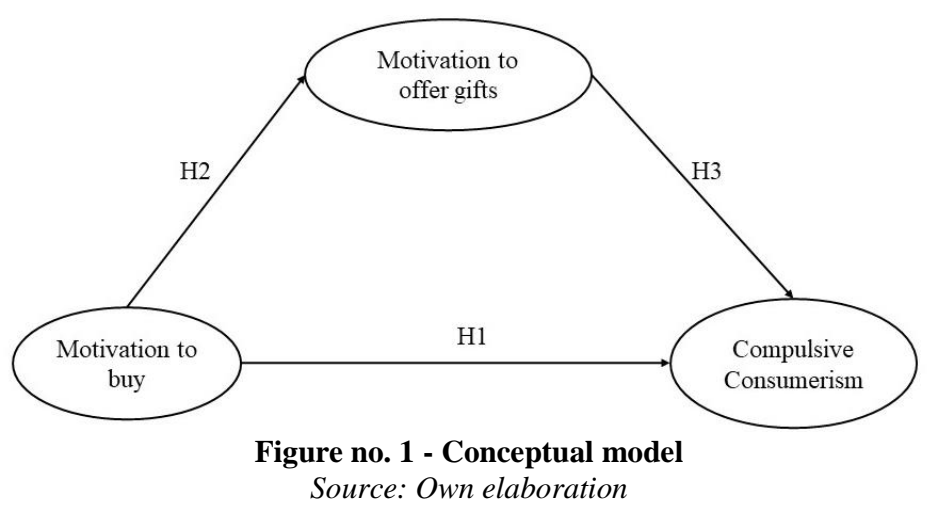

\section{METHODOLOGY}

\subsection{Population and Sample}

Portuguese over 18 years of age are the population chosen for this study. The data collection process took place between 1 and 23 December 2019, using the non-probabilistic method of sampling for convenience, due to the ease of access to the elements of the sample and the low associated cost.

The questionnaires were presented to the participants, accompanied by a small introductory summary defining the objectives of the study and guaranteeing the anonymity and confidentiality of the information provided.

After analyzing the questionnaires to sample consisted of 1086 Portuguese individuals over 18 years.

\subsection{Data Collection Instruments}

In the present investigation, in the data collection process, a quantitative methodology was used based on a questionnaire survey consisting of four parts. In the first part, individuals respond to compulsive consumerism. The second part analyzes the importance of activities associated with the Christmas season (see activities in Table no. 2) and the choice of gifts to offer at Christmas (see types of gifts in Table no. 3). In the third part, we study the motivations for offering gifts and for shopping at Christmas. In the fourth and last part, we asked the question with whom they usually spend Christmas with, and we asked also about the sociodemographic profile of the respondents which will be analyzed: sex, age, education level, marital status, religion, monthly household income and whether or not they have family members' dependents under 16 years old.

To analyze the compulsive consumerism construct, respondents answer about their degree of agreement regarding three items (Table no. 1), constructed taking into account the work of Araújo and Ramos (2010) and using a 5-point Likert scale (1 - Totally disagree to 5 - Strongly agree).

To measure the importance of activities associated with the Christmas season and the choice of different types of gifts to offer at Christmas, respondents assessed the degree of importance taking into account a 5-point Likert scale ( 1 - Not important to 5 - Very important). 
To analyze the motivation to offer gifts, five items were used (Table no. 1) based on Caplow (1984); Lemmergaard and Muhr (2011); Bueno (2014); Batinga et al. (2017); Corzo (2018); Ferreira (2019); Passos et al. (2020). These items were measured using a 5-point Likert scale (1- Not important to 5 - Very important).

The items of motivation to buy at Christmas time were based on Araújo and Ramos (2010) and are composed of nine descriptors (Table no. 1), being measured on a 5-point Likert scale of agreement (1-Strongly disagree to 5 - I totally agree).

Table no. 1 - Construct items under analysis

\begin{tabular}{l} 
Compulsive consumerism (CC) \\
CC1. At Christmas, when I am at the mall, I feel a sudden urge to buy something \\
CC2. At Christmas, when I go to the mall, I buy things I didn't plan \\
CC3. At Christmas, when I see something new and like it, I buy \\
\hline \multicolumn{1}{c}{ Motivation to offer gifts (MOG) } \\
MOG1. Affection \\
MOG2. Consolidation of social ties \\
MOG3. Reciprocity \\
MOG4. Recognition \\
MOG5. Ritual, culture and tradition
\end{tabular}

\section{Motivation to buy (MB)}

MB1. At Christmas I buy on credit, even if I'm not sure if I'll pay

MB2. At Christmas when I'm a little depressed, I like going to the mall to buy something

MB3. At Christmas buying something at the mall gives me a feeling of well-being

MB4. At Christmas shopping at the mall gives me a feeling of power

MB5. At Christmas I feel a need to buy just to feel like I bought something

MB6. At Christmas, going to the mall and shopping is a way to reduce stress

MB7. At Christmas I feel pleasure when I buy something that was not planned

MB8. At Christmas when I'm happy, I usually buy more

MB9. At Christmas if I go to the mall with some money, I look for a way to spend it

\section{Source: Own elaboration}

\subsection{Data analysis procedures}

After collecting the data, a database was built and in the statistical treatment of the data, software R version 4.02 (R Core Team, 2020) was used. In order to characterize the profile of the individuals and some descriptive analyzes, the use of descriptive statistics was used. The existence of outliers and the sensitivity of the items was assessed by using the coefficients of asymmetry $(|S k| \leq 3)$ and flatness $(|K u| \leq 7)$ according to the indications of Marôco (2018). The factorial validity of the model was assessed using the techniques of exploratory factor analysis since a structure is sought for the motivation to offer gifts, for the motivation to shop, and for compulsive consumerism at Christmas time.

Structural equation modeling with partial least squares (Partial Least Squares SEM PLS-SEM) was used, which is recommended to test and validate exploratory models that are in an early stage of theoretical development (Hair et al., 2011). On the other hand, PLS-SEM models have shown to be an alternative to the application of CB-SEM (Covariance-based SEM), as they are more flexible regarding the sample size and the absence of assumptions regarding the data distribution (Nitzl et al., 2016). 


\section{RESULTS AND DISCUSSION}

\subsection{Sociodemographic characterization}

As for the sociodemographic characterization, 1086 individuals are aged between 18 and 73 years, with an average of approximately 36 years $(S D=12.35)$ and most are female $(56.1 \%$, $n=609)$. As for the education level, $47.6 \%(n=517)$ have a degree, $25.6 \%(n=278)$ have Secondary Education (12th grade), $22.4 \%(n=243)$ have a master's or doctoral degree, and $4.4 \%(n=48)$ have up to Basic Education (9th grade). With regard to marital status, $45.9 \%$ $(n=498)$ are single, $45.2 \%(n=491)$ are married or live in a de facto union, and the remaining $8.9 \%(n=97)$ are separated, divorced or widowed. As for the household's monthly income, $41.2 \%(n=447)$ receive from 1001 to 2000 euros monthly, $23.7 \%(n=258)$ receive from 2001 to 3000 euros monthly, $17.7 \%(n=192)$ receive more than 3000 euros monthly, and $17.4 \%(n=189)$ receive up to 1000 euros monthly. Most individuals do not have a direct dependent relative under the age of $16(60.4 \%, n=657)$. Regarding the characterization of individuals in relation to the religion they profess, $87.1 \%(n=946)$ are Christian, $9.6 \%(n=$ $104)$ indicate to be Atheists, and $3.3 \%(n=36)$ are from other religions.

\subsection{Analysis of the importance given to activities and the choice of gifts at Christmas}

The overwhelming majority of individuals $(96.2 \%, n=1045)$ indicate that they spend Christmas with their family, $12(1.1 \%)$ indicate that they spend Christmas alone, $12(1.1 \%)$ with friends, $11(1 \%)$ with co-workers, $3(0.3 \%)$ with family and friends, $2(0.2 \%)$ with neighbors, and only $1(0.1 \%)$ does not celebrate Christmas.

Table no. 2 shows, in decreasing order of importance, the different activities that people usually perform at Christmas. It appears that people attach more importance to taking a trip to be with the family $(M=4.09, S D=1.09)$, having a Christmas tree at home $(M=3.95, S D$ $=1.17)$, have lunch or dinner with co-workers $(M=3.51, S D=1.09)$, participation in Christmas traditions $(M=3.45, S D=1.32)$, participation in the Christmas ceremony $(M=$ $3.21, S D=1.34)$, and gifts exchange $(M=3.17, S D=1.21)$.

Table no. 2 - Descriptive analysis of the importance given to the different activities carried out at Christmas

\begin{tabular}{lcc}
\hline & Mean & SD \\
\hline Taking a trip to be with the family & 4.09 & 1.09 \\
Having a Christmas tree at home & 3.95 & 1.17 \\
Have lunch / dinner with co-workers & 3.51 & 1.09 \\
Participation in Christmas traditions & 3.45 & 1.32 \\
Participation in the religious Christmas ceremony & 3.21 & 1.34 \\
Exchanging gifts & 3.17 & 1.21 \\
Going to a Christmas event near Home & 2.96 & 1.21 \\
Going to shows & 2.93 & 1.29 \\
Going to the movie theater & 2.92 & 1.31 \\
Visiting gardens & 2.75 & 1.27 \\
Visiting cathedrals and churches & 2.71 & 1.28 \\
See a live nativity scene & 2.67 & 1.21 \\
Reading (romances, novels, short stories, poetry) & 2.59 & 1.28
\end{tabular}




\begin{tabular}{lcc}
\hline & Mean & SD \\
\hline Going to classical music concerts & 2.58 & 1.27 \\
Going to the theater & 2.57 & 1.24 \\
Visiting places of architectural and heritage interest & 2.57 & 1.26 \\
Going to music festivals & 2.54 & 1.25 \\
Doing sports & 2.52 & 1.24 \\
Traveling abroad & 2.48 & 1.32 \\
Going to bookstores and libraries & 2.47 & 1.22 \\
Make a holiday trip & 2.46 & 1.25 \\
Go to art exhibitions and other & 2.42 & 1.20 \\
Visit museums & 2.33 & 1.16 \\
\hline
\end{tabular}

Source: Own elaboration

Table no. 3 shows, in descending order of importance, the types of gifts that people usually choose to offer at Christmas, and it is possible to observe that people give more importance to clothes or shoes $(M=3.64, S D=1.13)$, books $(M=3.55, S D=1.20)$, toys $(M$ $=3.49, S D=1.30)$, Chocolates $(M=3.40, S D=1.30)$, cosmetics or perfumes $(M=3.21, S D$ $=1.19)$ e wines $(M=3.20, S D=1.28)$. In Caplow's study $(1982)$, it was also found that the preference for clothing had preponderance over all other types of gifts. The importance given to "not offering gifts" is emphasized by the medium low level $(M=2.10, S D=1.19)$, which means that people give a lot of importance to the exchange of gifts.

Table no. 3- Descriptive analysis of the importance of the choice of gifts

\begin{tabular}{lcc}
\hline & Mean & SD \\
\hline Clothing / Footwear & 3.64 & 1.13 \\
Books & 3.55 & 1.20 \\
Toys & 3.49 & 1.30 \\
Chocolates & 3.40 & 1.30 \\
Cosmetics / perfumes & 3.21 & 1.19 \\
Wines & 3.20 & 1.28 \\
Christmas souvenirs & 2.78 & 1.29 \\
Liqueurs & 2.73 & 1.28 \\
Money & 2.72 & 1.34 \\
Vacation vouchers & 2.64 & 1.36 \\
Offer recognized brands & 2.62 & 1.19 \\
Shopping vouchers & 2.60 & 1.26 \\
Jewelry / Watches & 2.60 & 1.26 \\
Offer generic brands & 2.58 & 1.18 \\
Decorative ornaments & 2.40 & 1.28 \\
Do not offer gifts & 2.10 & 1.19 \\
\hline
\end{tabular}

Source: Own elaboration

\subsection{Exploratory factor analysis}

Before carrying out the measurement model evaluation using the structural equation modeling with partial least squares, an exploratory factor analysis (EFA) was applied to assess the structure of the measures under study. In applying this analysis, the principal component method and the Kaiser criterion (eigenvalues greater than 1) were used. The Kaiser-MeyerOlkin (KMO) indices and Bartlett's Sphericity Tests of the measures of compulsive 
consumerism $\left(\chi^{2}(3)=1803.157, p<0.001, \mathrm{KMO}=0.741\right)$, motivation to buy $\left(\chi^{2}(36)=\right.$ $8053.186, p<0.001, \mathrm{KMO}=0.947)$ and motivation to offer gifts $\left(\chi^{2}(10)=1623.903, p<\right.$ $0.001, \mathrm{KMO}=0.797$ ) revealed, according to Pestana and Gageiro (2014), a reasonable adequacy of the sample for the application of EFA (KMO $>0.7$ and $p<0.001)$. The three measures have a one-dimensional structure, where the three items of compulsive consumerism together account for $81.25 \%$ of the total variance, the nine items of motivation to buy together account for $70.30 \%$ of the total variance, and the five items of motivation to offer gifts together account for $55.60 \%$ of the total variance.

Then, to validate the results of the model, according to Henseler et al. (2009), it is necessary to validate the external model and then to validate the internal model.

\subsection{Evaluation of the Measurement Model}

In the evaluation of the measurement model, we begin by analyzing the loading. According to Hair et al. (2019), the loadings must present values greater than 0.708 to indicate that the construct explains more than $50 \%$ of the indicator's variance, thus providing an acceptable reliability of the item. Table no. 4 shows an item with loading lower than 0.708 (item MOG1) and all loadings for the remaining items are between 0.732 and 0.915 . The Affection item (MGO1) was not removed from the analysis as it is considered an important motivation for offering gifts (Batinga et al., 2017; Lemmergaard and Muhr, 2011).

The adequacy of the model is confirmed, since the loading of each indicator (shown in bold in Table no. 4) is greater than all its cross-loadings.

Table no. 4 - Discriminant validity: cross-loadings

\begin{tabular}{lccc}
\hline Items & Compulsive consumerism & Motivation to buy & Motivation to offer gifts \\
\hline CC1 & $\mathbf{0 . 8 9 7}$ & 0.619 & 0.223 \\
CC2 & $\mathbf{0 . 9 1 5}$ & 0.629 & 0.230 \\
CC3 & $\mathbf{0 . 8 9 2}$ & 0.653 & 0.204 \\
MB1 & 0.526 & $\mathbf{0 . 7 5 9}$ & 0.107 \\
MB2 & 0.584 & $\mathbf{0 . 8 4 4}$ & 0.132 \\
MB3 & 0.634 & $\mathbf{0 . 8 3 9}$ & 0.187 \\
MB4 & 0.594 & $\mathbf{0 . 8 7 5}$ & 0.186 \\
MB5 & 0.604 & $\mathbf{0 . 8 7 4}$ & 0.151 \\
MB6 & 0.568 & $\mathbf{0 . 8 8 0}$ & 0.155 \\
MB7 & 0.605 & $\mathbf{0 . 8 4 9}$ & 0.179 \\
MB8 & 0.576 & $\mathbf{0 . 7 6 7}$ & 0.145 \\
MB9 & 0.601 & $\mathbf{0 . 8 5 0}$ & 0.166 \\
MOG1 & 0.017 & -0.018 & $\mathbf{0 . 4 8 6}$ \\
MOG2 & 0.173 & 0.112 & $\mathbf{0 . 7 3 2}$ \\
MOG3 & 0.174 & 0.148 & $\mathbf{0 . 8 1 7}$ \\
MOG4 & 0.199 & 0.169 & $\mathbf{0 . 8 2 4}$ \\
MOG5 & 0.207 & 0.151 & $\mathbf{0 . 7 4 2}$ \\
\hline
\end{tabular}

Source: Own elaboration

Table no. 5 shows that Cronbach's alpha values and composite reliability of the constructs of compulsive consumerism, motivation to buy and motivation to offer gifts have adequate reliability, since these measures showed values greater than 0.7 (Hair et al., 2019). 
Convergent validity was evaluated by the value of the AVE (Average Variance Extracted) and was considered adequate for presenting values greater than 0.5 (see Table no. 5 ), which shows that the latent variables are able to explain, on average, more than half of the variance of the latent indicators (Hair et al., 2016).

To assess the discriminant validity, the correlations between the latent variables were calculated and these must be lower than the AVE's square root, so that the indicators have a stronger relationship with the corresponding latent variable compared to the other latent variables (Hair et al., 2016). The values of the AVE's square root (shown in bold in Table no. 5) are higher than the correlations between the constructs, so there is evidence of discriminant validity.

In short, the reliability and convergent and discriminant validity of the external model proved to be adequate, with no estimation problems.

Table no. 5 - Reliability, convergent and discriminant validity

\begin{tabular}{ccccccc}
\hline & CC & MB & MOG & Cronbach's Alpha & Composite Reliability & AVE \\
\cline { 2 - 7 } CC & $\mathbf{0 . 9 0 1}$ & & 0.885 & 0.929 & 0.812 \\
MB & $0.703^{* * * *}$ & $\mathbf{0 . 8 3 8}$ & & 0.947 & 0.955 & 0.703 \\
MO & $0.243^{* * *}$ & $0.188^{* * * *}$ & $\mathbf{0 . 7 3 1}$ & 0.798 & 0.848 & 0.534 \\
\hline Note: CC: Compulsive Consumerism, MB: Motivation to buy, MOG: Motivation to offer gifts. \\
*** p $<$ 0.001 \\
Source: Own elaboration
\end{tabular}

Table no. 6 shows that the Portuguese do not have high levels of compulsive consumerism. The Portuguese are very motivated to offer gifts, being the affection motivations $(M=4.19, S D=1.02)$, and consolidation of social ties $(M=3.65, S D=1.19)$ to present the higher levels. Regarding the motivation to buy, the Portuguese consider that, at Christmas time, when they are happy they usually buy more $(M=1.91, S D=1.11)$, and that buying something at the mall gives them the well-being feeling $(M=1.80, S D=1.07)$.

Table no. 6 - Descriptive statistics of the constructs under study

\begin{tabular}{|c|c|c|c|c|c|}
\hline \multirow{4}{*}{ Compulsive Consumerism } & & Mean & Standard Deviation & Skewness & Kurtosis \\
\hline & $\mathrm{CC} 1$ & 2.14 & 1.17 & 0.74 & -0.52 \\
\hline & $\mathrm{CC} 2$ & 2.11 & 1.16 & 0.83 & -0.34 \\
\hline & $\mathrm{CC} 3$ & 2.02 & 1.07 & 0.86 & -0.13 \\
\hline \multirow{5}{*}{ Motivation to offer gifts } & MOG1 & 4.19 & 1.02 & -1.64 & 2.46 \\
\hline & MOG2 & 3.65 & 1.19 & -0.84 & -0.20 \\
\hline & MOG3 & 3.42 & 1.28 & -0.59 & -0.80 \\
\hline & MOG4 & 3.36 & 1.32 & -0.50 & -0.98 \\
\hline & MOG5 & 3.18 & 1.28 & -0.35 & -1.04 \\
\hline \multirow{9}{*}{ Motivation to buy } & MB1 & 1.38 & 0.75 & 2.44 & 6.46 \\
\hline & MB2 & 1.57 & 0.92 & 1.81 & 2.81 \\
\hline & MB3 & 1.80 & 1.07 & 1.23 & 0.46 \\
\hline & MB4 & 1.58 & 0.91 & 1.68 & 2.23 \\
\hline & MB5 & 1.52 & 0.86 & 1.87 & 3.23 \\
\hline & MB6 & 1.58 & 0.92 & 1.67 & 2.18 \\
\hline & MB7 & 1.69 & 0.99 & 1.47 & 1.45 \\
\hline & MB8 & 1.91 & 1.11 & 1.07 & 0.11 \\
\hline & MB9 & 1.59 & 0.93 & 1.74 & 2.54 \\
\hline
\end{tabular}




\subsection{Evaluation of the Structural Model}

According to Hair et al. (2016), VIF (Variance Inflation Factor) values below 5 are recommended to avoid collinearity problems between the predictor constructs. The analysis of the VIF values showed that there are no collinearity problems, given that the VIF values are 1.000 and 1.036 .

The determination coefficients $\left(R^{2}\right)$ evaluate the percentage of variance explained by the dependent variables in the structural model. Thus, the motivation to buy explains $3.5 \%\left(R^{2}=\right.$ 0.035 ) of the variance of the motivation to offer gifts, and the motivation to buy, together with the motivation to offer gifts explains $50.7 \%\left(R^{2}=0.507\right)$ of the variance of the compulsive consumerism. These values in the area of social and behavioral sciences, according to Cohen (1988), are considered a small and a large effect, respectively ( $2 \%$ is classified as a small effect, $13 \%$ as a medium effect, and $26 \%$ as a large effect).

Predictive validity $\left(Q^{2}\right)$, also known as the Stone-Geisser indicator or cross-validity redundancy, assesses how close the model is to what was expected of it. $Q^{2}$ values greater than $0,0.25$, and 0.50 represent small, medium and large predictive relevance of the PLS path model (Hair et al., 2019). Thus, the motivation to buy has little predictive relevance in the motivation to offer gifts $\left(Q^{2}=0.019\right)$, and the motivation to buy together with the motivation to offer gifts has average predictive relevance in consumerism $\left(Q^{2}=0.412\right)$.

The size of the $f^{2}$ effect makes it possible to evaluate the contribution of an exogenous construct to the $R^{2}$ value of an endogenous latent variable. The size of the $q^{2}$ effect makes it possible to assess the contribution of an exogenous construct to $Q^{2}$ of an endogenous latent variable. The values of $f^{2}$ and $q^{2}$ of $0.02,0.15$, and 0.35 indicate a weak effect, moderate effect, and strong effect of an exogenous construct, respectively, in an endogenous construct (Cohen, 1988).

In Table no. 7, the empirical results show that the motivation to buy positively influences compulsive consumerism at Christmas time $(\beta=0.681, t=31.40, p<0.001)$, supporting the H1 hypothesis empirically. The effect sizes $\left(f^{2}=0.910, q^{2}=0.620\right)$ are classified as strong (Cohen, 1988). The result supported by Hypothesis 1 is witnessed in the literature, through studies Araújo and Ramos (2010), and Fernandes (2020), who consider that social status is projected through impulse purchases. According to Penaloza et al. (2018), the strong desire to consume induces an irresistible urge to act, often in an unbridled way. Positive emotions and purchase approval by friends lead to a greater trend towards impulse buying.

The motivation to buy also positively influences the motivation to offer gifts during the Christmas season $\left(\beta=0.188, t=6.31, p<0.001, f^{2}=0.036, q^{2}=0.019\right)$, which empirically supports the $\mathrm{H} 2$ hypothesis. This positive influence between the motivation to buy and the motivation to offer gifts at Christmas time is understood as the biggest consumer event of the year (Pinto and Cruz, 2014), being the mythical figure of Santa Claus (Levi-Strauss, 2003) to reinforce a greater link between brands and commerce at Christmas time (Gonçalves, 2020).

The H3 hypothesis is also supported empirically. In other words, the motivation to offer gifts positively influences compulsive consumerism at Christmas time $(\beta=0.115, t=5.28, p$ $<0.001, f^{2}=0.026, q^{2}=0.017$ ). Note that the effect sizes in hypotheses $\mathrm{H} 2$ and $\mathrm{H} 3$ are classified as weak (Cohen, 1988). The result supported by Hypothesis 3 corroborates with the literature, as the word gift is related to consumerism (Gonçalves, 2020). The gifts carry meanings (Corzo, 2018). A gift reveals sympathy, appreciation, and for Christians the gifts 
also express the joy at the birth of Jesus, since Jesus also received gifts at his birth (Ferreira, 2019). The exchange of gifts is culture and tradition (Bueno, 2014; Corzo, 2018).

To analyze the indirect effect of the motivation to buy on consumerism through the motivation to offer gifts, the $95 \%$ confidence interval was determined through 5,000 resamples in the bootstraping procedure (CI 95\% with limits ]0.010,0.035[), verifying that the range does not include zero, which indicates that the indirect effect $(0.0216)$ is significant. Thus, it can be said that the motivation to offer gifts plays a mediating role in the relationship between the motivation to buy and compulsive consumerism at Christmas time.

Table no. 7 - Results of the Structural Model Analysis

\begin{tabular}{lccccc}
\hline \multicolumn{1}{c}{ Path } & Coefficient & $\boldsymbol{t}$-value & $\boldsymbol{p}$ & $\boldsymbol{f}^{\mathbf{2}}$ & $\boldsymbol{q}^{\mathbf{2}}$ \\
\hline $\mathrm{H} 1: \mathrm{MB} \rightarrow \mathrm{CC}$ & 0.681 & 31.40 & 0.000 & 0.910 & 0.620 \\
$\mathrm{H} 2: \mathrm{MB} \rightarrow \mathrm{MOG}$ & 0.188 & 6.31 & 0.000 & 0.036 & 0.019 \\
$\mathrm{H} 1: \mathrm{MOG} \rightarrow \mathrm{CC}$ & 0.115 & 5.28 & 0.000 & 0.026 & 0.017 \\
\hline
\end{tabular}

Note: C: Compulsive Consumerism, MB: Motivation to buy, MOG: Motivation to offer gifts.

Source: Own elaboration

\section{CONCLUSIONS}

This article aimed to analyze a conceptual model composed of the variables motivation to buy, motivation to offer gifts and consumerism in the Christmas season. In Portugal, the image of Santa Claus is associated with the tradition of offering gifts and people give much importance to Christmas and ritual of offering gifts. Love, affection, affectivity and family are the most relevant aspects for the happiness of Christmas. During Portuguese Christmas, the streets are filled with decorations alluding to the time, the shopping malls are filled with people, and Christmas campaigns take place to help with the purchase of gifts and the legitimacy to acquire material goods. Christmas is the celebration that gathers the family, children's party, where there is greater sensitivity and practiced solidarity with the most disadvantaged.

Based on a sample of 1086 Portuguese individuals over the age of 18, it was found that the Christmas activities that have the highest degree of importance are: taking a trip to be with the family, having a Christmas tree at home, having lunch or dinner with colleague's work, participation in Christmas traditions and participation in the Christmas ceremony. The Portuguese also give great importance to the gifts exchanging. They consider clothes or shoes, books, toys, chocolates, cosmetics or perfumes, and wines as the most important gifts.

A conceptual model composed of the variables motivation to buy, motivation to offer gifts and compulsive consumerism at Christmas time was also analyzed. The results show that the measures used presented adequate convergent and discriminant reliability and validity.

The Portuguese did not show high levels of compulsive consumerism, but they are motivated to offer gifts, their motivations being the affection and the consolidation of the social ties that presented the highest average levels. Regarding the motivation to buy at Christmas time, they consider that when they are happy they usually buy more, and buying something at the mall gives them a feeling of well-being.

The results of the conceptual model show that the motivation to buy and the motivation to offer gifts positively influence compulsive consumerism at Christmas time, and that the motivation to buy positively influences the motivation to offer gifts at Christmas time. The 
model contains the mediating variable motivation to offer gifts, so it was concluded that the motivation to offer gifts has a mediating role in the relationship between the motivation to buy and compulsive consumerism at Christmas time.

In this investigation, some limitations were observed, one of them and the main one being the non-existence of many research works on Christmas in the literature, especially in Portugal, thus, it was not possible to compare some aspects addressed with existing literature, which, perhaps, could impoverish the discussion.

The present study can help academics, researchers and professionals (managers of consumer goods companies, commercial managers and advertising campaign managers) to better understand the motivations for buying and offering gifts, and the compulsive consumerism of the Portuguese population at Christmas time.

It can be said that this study makes an attractive contribution to marketing and consumption studies, in the sense of unveiling Christmas gifts and compulsive consumption during the Christmas season. It can also be said that there is a contribution towards understanding the motivation for offering gifts, and in the Portuguese case, it is the affections and the consolidation of social ties.

In the future, we intend to study the relevance of symbols at Christmas time and understand their importance for adults and children. The importance of this study is also emphasized, as it will serve as a "landmark", since it was carried out before the appearance of the COVID-19 pandemic in Portugal. The COVID-19 pandemic completely changed people's lives from one day to the other. Christmas 2020 was not the same as all others, due to the measures adopted by governments to reduce the spread of the virus, for example, limiting the number of people who can gather on Christmas Eve. These facts can affect family ties, as well as the motivation to buy and offer gifts, and, as a consequence, consumerism. Thus, it is considered interesting to replicate the study next Christmas 2021.

\section{ORCID}

Eulália Santos iD https://orcid.org/0000-0001-8069-2657

Ana Diogo (iD https://orcid.org/0000-0003-4939-9158

Vanessa Ratten iD https://orcid.org/0000-0002-2534-4550

Fernando Oliveira Tavares (iD http://orcid.org/0000-0002-9672-8770

\section{References}

Araújo, G. P., and Ramos, A. S. M., 2010. Comportamento de compra por impulso em shopping centers: Pesquisa com consumidores de Brasilia-DF e Natal-RN. REAd-Revista Eletrônica de Administração, 16(3), 589-610.

Batinga, G. L., Pinto, M. D. R., and Resende, S. P., 2017. Christmas, consumption and materialism: discourse analysis of children's Christmas letters. Revista Brasileira de Gestao de Negocios, 19(66), 557-573. http://dx.doi.org/10.7819/rbgn.v0i0.3429

Belk, R. W., and Bryce, W., 1993. Christmas Shopping Scenes: From Modern Miracle to Postmodern Mall. International Journal of Research in Marketing, 10(3), 277-296. http://dx.doi.org/10.1016/0167-8116(93)90011-M 
Bueno, C. M. F. R., 2014. Seguindo a estrela: a Adoracao dos Reis Magos na construcao de um novo espaco composicional na pintura italiana dos seculos XIV e XV: Tese de Doutoramento em Teoria e Historia da Arte, Universidade de Brasilia.

Canhoto, J. M., 2018. A árvore de Natal na perspetiva de um biólogo. Revista de Ciência Elementar, 6(4). http://dx.doi.org/10.24927/rce2018.079

Caplow, T., 1982. Christmas gifts and kin networks. American Sociological Review, 47(3), 383-392. http://dx.doi.org/10.2307/2094994

Caplow, T., 1984. Rule enforcement without visible means: Christmas gift giving in Middletown. American Journal of Sociology, 89(6), 1306-1323. http://dx.doi.org/10.1086/228017

Clarke, P., 2007. A measure for Christmas spirit. Journal of Consumer Marketing, 24(1), 8-17. http://dx.doi.org/10.1108/07363760710720948

Clarke, P., and McAuley, A., 2010. Parental evaluation of popular brand names given as Christmas gifts and sources of information used in these decisions. Journal of Consumer Marketing, 27(6), 534542. http://dx.doi.org/10.1108/07363761011078271

Cohen, J., 1988. Statistical power analysis for the behavioral sciences: Erlbaum.

Corzo, S., 2018. La cultura del regalo: comportamiento del consumidor en los distintos paises: Trabajo de Fin de Grado, Facultad de Ciencias Economicas y Empresariales, Universidad de Valladolid.

Deloitte, 2018. Enlighten your Christmas - Christmas Survey 2018. Perceção e Hábitos de Consumo. from https://www2.deloitte.com/pt/pt/pages/about-deloitte/articles/estudo-de-natal-2018comunicado.html

Deloitte, 2019. The magic of Christmas - Christmas Survey 2019 - Portuguese results. from https://www2.deloitte.com/content/dam/Deloitte/pt/Documents/consumer-business/estudosnatal/EstudoNatal2019/XmasSurvey2019_Portugal.pdf

Fernandes, S. P., 2020. Everything Now: a influência do grupo de amigos na compra por impulso de bilhetes de festivais de música para a área VIP. (Dissertação do Mestrado Integrado em Psicologia das Organizações, Social e do Trabalho), Universidade do Porto.

Ferreira, N. M. R., 2019. Natal: celebração cristã e festa social: proposta de abordagem à UL 2: Advento e Natal, do $5^{\circ}$ ano de escolaridade. (Dissertação de Mestrado), Universidade Católica Portuguesa.

Fischer, E., and Arnold, S. J., 1990. More than a labor of love: Gender roles and Christmas gift shopping. The Journal of Consumer Research, 17(3), 333-345. http://dx.doi.org/10.1086/208561

Goidanich, M. E., 2008. Diz-me se no Natal serves Chester ou Peru e te direi quem es. Revista Internacional Interdisciplinar INTERthesis, 5(2), 104-119.

Gonçalves, B. C. A., 2020. Happy sad christmas!: fatores influenciadores da compra por impulso de prendas de natal. (Dissertação de Mestrado ), Universidade do Porto.

Hair, J. F., Hult, G. T. M., Ringle, C., and Sarstedt, M., 2016. A primer on partial least squares structural equation modeling (PLS-SEM): Sage Publications.

Hair, J. F., Ringle, C. M., and Sarstedt, M., 2011. PLS-SEM: Indeed a silver bullet. Journal of Marketing Theory and Practice, 19(2), 139-152. http://dx.doi.org/10.2753/MTP1069-6679190202

Hair, J. F., Risher, J. J., Sarstedt, M., and Ringle, C. M., 2019. When to use and how to report the results of PLS-SEM. European Business Review, 31(1), 2-24. http://dx.doi.org/10.1108/EBR-11-20180203

Henseler, J., Ringle, C. M., and Sinkovics, R. R., 2009. The use of partial least squares path modeling in international marketing. In R. R. Sinkovics and P. N. Ghauri (Eds.), New Challenges to International Marketing (Vol. 20, pp. 277-319): Emerald Group Publishing Limited. http://dx.doi.org/10.1108/S1474-7979(2009)0000020014

Kisbu-Sakarya, Y., MacKinnon, D. P., Valente, M. J., and Cetinkaya, E., 2020. Causal Mediation Analysis in the Presence of Post-treatment Confounding Variables: A Monte Carlo Simulation Study. Frontiers in Psychology, 11, 2067. http://dx.doi.org/10.3389/fpsyg.2020.02067

Lemmergaard, J., and Muhr, S. L., 2011. Regarding gifts - on Christmas gift exchange and asymmetrical business relations. Organization, 18(6), 763-777. http://dx.doi.org/10.1177/1350508411416402 
Levi-Strauss, C., 2003. Introducao a obra de Marcel Mauss. Sociologia \& Antropologia, 2, 37-184.

Lopes, M. A., 2012. Os alimentos nos rituais familiares portugueses (1850-1950). In M. M. L. d. Araujo, A. C. Lazaro, A. Ramos and A. Esteves (Eds.), O tempo dos alimentos e os alimentos no tempo (Vol. 2012, pp. 167-179). Braga: CITCEM.

Marôco, J., 2018. Análise estatística com o SPSS Statistics 25 (7th ed.). Lisboa, Portugal.

Mesquita, J. C. V., 1982. Tradições do Natal Português. from https://sapientia.ualg.pt/handle/10400.1/5665

Nicolás Ojeda, M. A., Martínez Pastor, E., and García Manso, A., 2019. Un estudio de las representaciones familiares y socioafectivas en la publicidad de juguetes en Navidad. Doxa Comunicación. Revista Interdisciplinar De Estudios De Comunicación Y Ciencias Sociales, 28, 151-169. http://dx.doi.org/10.31921/doxacom.n28a08

Nitzl, C., Roldan, J. L., and Cepeda, C. G., 2016. Mediation analysis in partial least squares path modeling: Helping researchers discuss more sophisticated models. Industrial Management \& Data Systems, 116(9), 1849-1864. http://dx.doi.org/10.1108/IMDS-07-2015-0302

O'Cass, A., and Clarke, P., 2001. Dear Santa, do you have my brand? A study of the brand requests, awareness and request styles at Christmas time. Journal of Consumer Behaviour, 2(1), 37-53. http://dx.doi.org/10.1002/cb.88

Passos, S., Leite, R., and Pinto, M. D., 2020. Personal values and gift giving act: A proposed connection. Estudios Gerenciales, 36(155), 218-228. http://dx.doi.org/10.18046/j.estger.2020.155.3539

Penaloza, V., Portela, M., Gerhard, F. S. O., and Quezado, I., 2018. Representação social da compra por impulso por consumidores de baixa Renda. Consumer Behavior Review, 2(1), 1-12. http://dx.doi.org/10.51359/2526-7884.2018.15037

Pestana, M. H., and Gageiro, J. N., 2014. Analise de dados em Ciencias Sociais - A complementaridade do SPSS (6th ed. ed.): Silabo.

Pinto, M., and Cruz, R. C., 2014. Experiências de consumo no Natal de cidades do interior de Minas Gerais. Gestão \& Regionalidade, 30(89), 35-48. http://dx.doi.org/10.13037/gr.vol30n89.1918

$\mathrm{R}$ Core Team, 2020. R: A language and environment for statistical computing. $R$ Foundation for Statistical Computing, Vienna, Austria. from https://www.R-project.org/

Santos, A. C., and Musse, C. F., 2016. A festa de Natal para o cineasta amador: Como a Kodak Movie News incentivou a producao e o consumo de imagens familiares. Rizoma, 4(2), 281-295. http://dx.doi.org/10.17058/rzm.v4i2.8075

Santos, E., and Tavares, F., 2020. Consumerism perception in Portugal at Christmas time. Revista de Gestão dos Países de Lingua Portuguesa, 19(3), 163-179. http://dx.doi.org/10.12660/rgplp.v19n3.2020.81233

Silva, A. C. D., 2017. Natal, a celebração da dádiva: proposta de abordagem à UL 2: Advento e Natal, do $5^{\circ}$ ano de escolaridade. (Dissertação de Mestrado), Universidade Católica Portuguesa.

Storni, M. O., and Estima, L. D., 2010. A religião como produto de consumo: Reflexões. Caos-Revista Eletrônica de Ciências Sociais, João Pessoa, 1(15), 15-28.

Tavares, F. O., Pacheco, L., and Sousa, P. F., 2014. Análise dos fatores de atratividade dos shoppings centers no Porto, Portugal. Revista de Negócios, 19(4), 84-102. http://dx.doi.org/10.7867/1980 4431.2014v19n4p84-102

\section{Copyright}

(i) $(-)$ This article is an open access article distributed under the terms and conditions of the ${ }_{\mathrm{EY}} \mathrm{NO} \mathrm{ND}$ Creative Commons Attribution-NonCommercial-NoDerivatives 4.0 International License. 